\title{
ANALYZING FACTORS AFFECTING THE ENTREPRENEURIAL ORIENTATION OF AGRICULTURAL UNIVERSITY STUDENTS
}

\author{
Hartono Rachman, Nugroho Tri Wahyu, Rahman M. Shadiqur \\ Department of Agricultural Socio-Economics, University of Brawijaya, Malang, Indonesia \\ E-mail: rachman.fp@ub.ac.id
}

\begin{abstract}
This research is to analyze factors affecting the entrepreneurial orientation focused on agricultural university students. The research location was the Faculty of Agriculture (University of Brawijaya) with a total sample of 340 students. The data analysis to answer the research problems was Structural Equation Modeling (SEM). SEM is a statistical method allowing testing a series of relatively complex relationships simultaneously. The relationship can be developed from one or several dependent variables with one or several independent variables. Both variables are in the form of factors (constructs consisted of several indicators). The results show that the perception of structural support has direct and indirect effects on the entrepreneurial orientation of individual students. Furthermore, the perception of educational support does not directly affect the students' IEO. However, the perception of educational support would affect IEO when mediated by self-efficacy.
\end{abstract}

\section{KEY WORDS}

Entrepreneurial orientation, agricultural university, students, structural equation modeling.

Over the course of time, entrepreneurship has become an essential need for most people, not only to fulfill their needs but also for the sustainability of their livelihoods (Audretch, 2007). Building awareness of the significance of entrepreneurship in community is crucial. It must be begun at an early age, so it needs to be designed in the education to foster entrepreneurial skills in young generation (World Economic Forum, 2009).

Many researches have explained the importance of entrepreneurship education. One of them was Turker \& Skluck (2009) who explained that education offered by educational institutions affected the students' choices in determining their career, especially in entrepreneurship. On the other hand, entrepreneurship education in university was seen as vital to enhance economic growth since it had a significant effect on the students' opportunities for entrepreneurship (Giacomin et al., 2011). The results of the research conducted by Turker \& Selcuk (2009) found that students' entrepreneurial orientation was affected by educational support and structural support. Nonetheless, some of the previous literature related to students' propensity to entrepreneurship was mostly involving business university students. AS we know that university has many departments, one of which is the Department of Agriculture. In this department, entrepreneurship education is one of the important courses and prioritized for the development of students' abilities. Moreover, Agriculture is a department with various products and services that are potential for business. Therefore, the research on the factors affecting the entrepreneurial orientation focused on agricultural students need to be conducted.

\section{LITERATURE REVIEW}

As explained earlier, where Entrepreneurial Orientation (EO) can be applied to individuals so that the entrepreneurial orientation application is the same as its application in the company (Robinson \& Stubberrud, 2014). Several studies have explained that EO has three dimensions including; innovative, proactive, and risk taking.

Self-Efficacy describes the nature of one's abilities. Mcgee \& Peterson (2017) define self-efficacy as a strong personal belief in individual's ability to begin a task and bring it to success. Some researchers have explained that self-efficacy is an important component to 
predict initial intention in business and personal success (Krueger et al., 2000). Therefore, Kropp et al. (2008) use self-efficacy as a factor to measure EO in companies. On the other hand, Drnovsek, Wincent \& Cardon, (2010) found that self-efficacy is a positive attribute in the business world. So, it can be concluded that self-efficacy has a positive effect on the entrepreneurial orientation.

EO is a learning process to obtain entrepreneurial information that provides insight, enhances awareness and strong entrepreneurial mentality. Various literatures have explained that entrepreneurship can be taught and learned (Yusoff, Ahmad \& Halim, 2016). Entrepreneurial education seems to increase individual ability in entrepreneurship (Matlay, 2008). On the other hand, researchers have found that entrepreneurial education in university has a positive effect on the students' entrepreneurial orientation (Gelard, 2011). In addition, Gorman et al., (1997) explain that educational program also has a positive effect on the individual entrepreneurial characteristics. Therefore, it can be conclude that education and training programs have a strong relationship with entrepreneurship.

In addition to gaining knowledge about entrepreneurship, education also help individuals to improve self-efficacy to achieve success in business (Gelaidan \& Abdullateef, 2017). Therefore, knowledge about entrepreneurship can encourage individuals to adopt entrepreneurship.

One of the factors affecting individual EO is the environment. Several studies explained that there was a positive relationship between EO and environment including family, friend, and community (Holienka, Myra \& Marcin, 2013). For example; someone whose parent is an entrepreneur will have a higher EO. Hence, it can be concluded that relational support has a positive effect on EO. On the other hand, relational support also has a relationship with selfefficacy. The supportive environment encourages a person to be more confident and enthusiastic in entrepreneurship (Ismail et al., 2009).

Structural support is one of the contributing factors in EO where the context of entrepreneurship is currently formed by economic and political tools set by individuals in the public, private, and government sectors. Thus, the system can provide a threat to businessmen, such as the rules that can limit businessmen to innovate for business development. Nevertheless, if the regulation supports the business development, businessmen are more likely to develop their business (Gelard \& Saleh, 2011).

\section{METHODS OF RESEARCH}

The respondents in this research were students of the Faculty of Agriculture, Brawijaya University, from the classes of 2016 to 2018 with consideration of accessibility where those students were still taking courses so it was easy to meet them. Simple random sampling method was used for determining the respondents in this research. The number of samples was determined through sample size simple random sampling method. From 2797 students, the sample size obtained through simple sample size sampling method was 419 students.

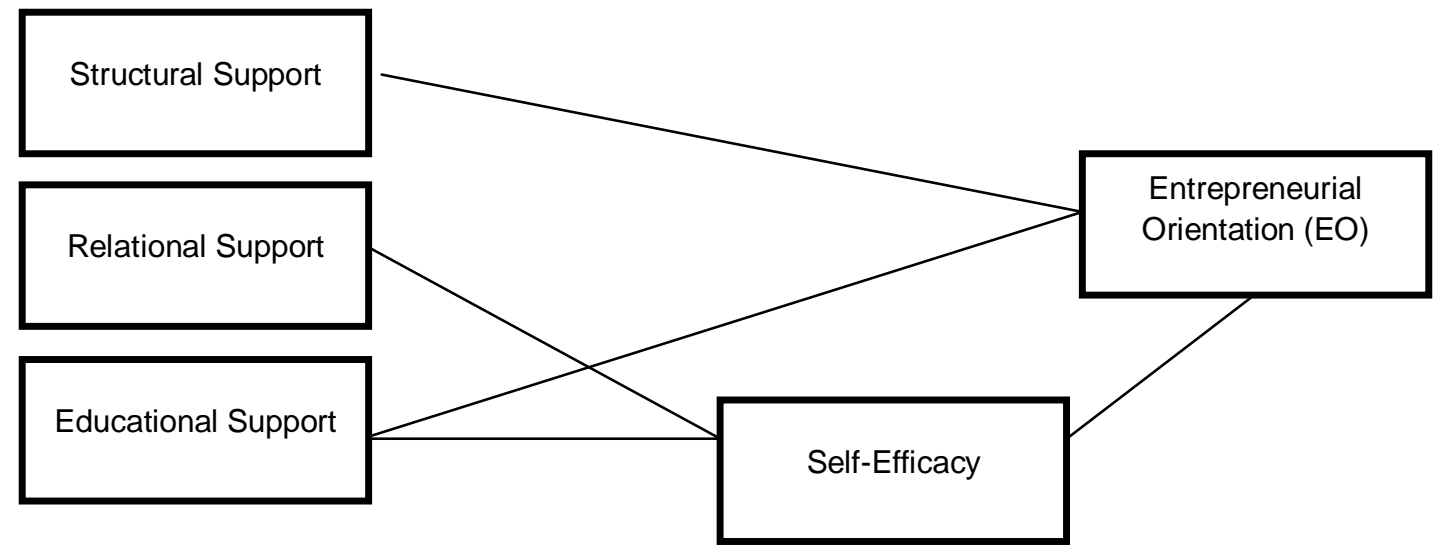

Figure 1 - Research Framework 


\section{RESULTS AND DISCUSSION}

To measure the level of students' entrepreneurial orientation and its affecting factors, this research adopted the questions used by (Lumpkin \& Dess, 1996). . Each question was measured using Likert scale where the value of 1 for strongly disagree, 2 for disagree, 3 for neutral, 4 for agree and 5 for strongly agree. Table 2 consists of questions to measure the students' entrepreneurial orientation and it's affecting factors.

Table 2 - Descriptive Statistics

\begin{tabular}{|c|c|c|}
\hline Variable & Mean & Std. Dev. \\
\hline \multirow{2}{*}{\multicolumn{3}{|c|}{$\begin{array}{l}\text { 1. Individual Entrepreneurial Orientation } \\
\text { a. Proactive }\end{array}$}} \\
\hline & & \\
\hline \multirow{2}{*}{$\begin{array}{l}\text { When dealing with other people, I usually respond to the actions taken by others. } \\
\text { When dealing with other people, I usually initiate actions that other people respond } \\
\text { to. }\end{array}$} & 2.86396 & 0.92964 \\
\hline & 3.52506 & 0.83076 \\
\hline In a group, I usually start to use new products/services. & 3.07399 & 0.84817 \\
\hline $\begin{array}{l}\text { In confrontational situation, I usually adopt direct and competitive attitude. } \\
\text { b. Risk taking }\end{array}$ & 3.74702 & 0.84319 \\
\hline In general, I tend to do business with high risk. & 3.38664 & 0.86584 \\
\hline I believe that courage is a necessary. & 3.56325 & 0.90595 \\
\hline $\begin{array}{l}\text { When faced with a decision-making situation involving uncertainty, I usually adopt } \\
\text { bold and aggressive attitude to maximize potential opportunities. } \\
\text { 2. Self-Efficacy }\end{array}$ & 4.19093 & 0.72006 \\
\hline Starting a business is easy for me. & 2.86396 & 0.89556 \\
\hline I know how to develop an entrepreneurial project. & 3.1957 & 0.86111 \\
\hline $\begin{array}{l}\text { If I try to start a business, I will have a high probability of success. } \\
\text { 3. Perception of Educational Support }\end{array}$ & 3.57041 & 0.82814 \\
\hline $\begin{array}{l}\text { Education in my university encourages me to develop creative ideas to become an } \\
\text { entrepreneur. }\end{array}$ & 4.0716 & 0.80941 \\
\hline My university provides necessary knowledge about entrepreneurship. & 4.05728 & 0.80463 \\
\hline $\begin{array}{l}\text { My university develops my entrepreneurial skills and abilities. } \\
\text { 4. Perception of Relational Support }\end{array}$ & 3.83294 & 0.86989 \\
\hline If I decide to be an entrepreneur, my family will support me. & 4.4105 & 0.76932 \\
\hline $\begin{array}{l}\text { If I decide to be an entrepreneur, my friends will support me. } \\
5 \text {. Perception of Structural Support }\end{array}$ & 4.3389 & 0.71531 \\
\hline $\begin{array}{l}\text { In Indonesia, entrepreneurs are driven by structural system including private, public, } \\
\text { and non-government organizations. }\end{array}$ & 3.97136 & 0.78511 \\
\hline Economy in Indonesia provides many opportunities for entrepreneurs. & 3.95704 & 0.82894 \\
\hline Indonesian laws (rules and regulations) are not suitable for doing business. & 3.04535 & 0.86691 \\
\hline
\end{tabular}

Table 3 - Validity Test and Reliability Test

\begin{tabular}{ccccccc}
\hline Item & Obs & Sign & Item-Test Correlation & Item-Test Correlation & Average Interitem Covariance & Alpha \\
\hline p1 & 419 & + & 0.3456 & 0.2339 & 0.1631726 & 0.8415 \\
p2 & 419 & + & 0.5056 & 0.4193 & 0.1562617 & 0.8311 \\
p3 & 419 & + & 0.3782 & 0.2789 & 0.162136 & 0.8382 \\
p4 & 419 & + & 0.6528 & 0.5833 & 0.1489778 & 0.8227 \\
r1 & 419 & + & 0.6202 & 0.5440 & 0.1500253 & 0.8246 \\
r2 & 419 & + & 0.5436 & 0.4533 & 0.1530882 & 0.8294 \\
r3 & 419 & + & 0.4540 & 0.3757 & 0.1603062 & 0.8332 \\
s1 & 419 & + & 0.5175 & 0.4252 & 0.1546072 & 0.8309 \\
s2 & 419 & + & 0.5778 & 0.4964 & 0.1522163 & 0.8272 \\
s3 & 419 & + & 0.5992 & 0.5239 & 0.1518817 & 0.8259 \\
pp1 & 419 & + & 0.6409 & 0.5729 & 0.1503715 & 0.8236 \\
pp2 & 419 & + & 0.6028 & 0.5303 & 0.1522387 & 0.8257 \\
pp3 & 419 & + & 0.5768 & 0.4944 & 0.1520894 & 0.8272 \\
pr1 & 419 & + & 0.4461 & 0.3614 & 0.1599185 & 0.8338 \\
pr2 & 419 & + & 0.5264 & 0.4548 & 0.1574267 & 0.8298 \\
ps1 & 419 & + & 0.4963 & 0.4142 & 0.1574502 & 0.8314 \\
ps2 & 419 & + & 0.5172 & 0.4323 & 0.1557429 & 0.8305 \\
ps3 & 419 & + & 0.2259 & 0.1643204 & 0.8410 \\
\hline Test Scale & 0.3306 & & & 0.1556795 & \\
\hline Reliability Statistic (Cronbach's Alpha) $=0.838$ &
\end{tabular}


The validity test in this research uses $95 \%$ confidence level with a level of 0.05 in table $R$ with a value of 0.098 with a total of 419 respondents. The Validity Test Results in the table below state that each component of the question had a validity value of $>0.098$. It shows that the items to obtain the research data are valid. Furthermore, the Reliability Test Result (Cronbach's Alpha) is $0.838>$ from the $r$ table. Hence, it can be concluded that the questionnaire used in this research is reliable.

Goodness of fit (GOF) testing is needed for the goodness of the model in the research. Some statistical tests were carried out to determine the goodness of the model in this research. As shown in table 4, the Root Mean Square Error of Approximation (RMSEA) value is $0.060 \leq 0.06$ (Hu and Bentler 1999) meaning that the RMSEA statistical test results show good fit. The comparative Fit Index (CFI) Test obtains a value of $0.909>0.90$ (Huber \& Crop, 2014). From the results of the CFI test, the model in this research is a good fit. Furthermore, TLI test obtains values of $0.889<0.889$ and $>0.80$ (Huber \& Crop, 2014). Tucker-Lewis Index (TLI) statistical test results show that the model used in this research is Adequate fit. Finally, the Standardized Root Mean Square Residual (SRMR) test results obtain a value of $0.06<0.08$ (Huber \& Crop, 2014). These results indicate that the model used in this research is a Good Fit. From those statistical tests to determine the GOF of a model, it can be concluded that the model used in this research is GOF.

Table 4 - Goodness of Fit

\begin{tabular}{cccc}
\hline Indicator & Result & Criteria & Description \\
\hline RMSEA & 0.06 & $\leq 0.06$ & good fit \\
CFI & 0.909 & $>0.90$ & good fit \\
TLI & 0.889 & $>0.95$ & Adequate fit \\
SRMR & 0.06 & $<0.08$ & good fit \\
\hline
\end{tabular}

Table 5 is the result of structural equation model (SEM) analysis to analyze the factors affecting the entrepreneurial orientation of the students of the Faculty of Agriculture, University of Brawijaya. The correlation between self-efficacy and entrepreneurial orientation has a coefficient of 0.250193 with a significance of 0.000 . This shows that self-efficacy has a positive and significant effect on the students' entrepreneurial orientation. The correlation between perception of educational support and entrepreneurial orientation obtains a coefficient value of 0.014827 with a significance level of 0.741 . It shows that perception of educational support has no significant effect on the entrepreneurial orientation. The perception of structural support obtains a coefficient value of 0.183487 with a significance level of 0.031 . It shows that the perception of structural support has a positive and significant effect on the entrepreneurial orientation. The correlation between perception of relational support and entrepreneurial orientation obtains a coefficient value of 0.038887 with a significance level of 0.398 . It shows that the perception of relational support has no significant effect on the entrepreneurial orientation.

Table 5 - Structural Equation Model

\begin{tabular}{lllll}
\hline Structural & Coef & Std. Err & z & Probability \\
\hline Entrepreneurial Orientation & & & & \\
Self-Efficacy & 0.250193 & 0.054188 & 4.62 & $0.000^{* * *}$ \\
Educational Perception & 0.014827 & 0.044869 & 0.33 & 0.741 \\
Structural Perception & 0.183487 & 0.085051 & 2.16 & $0.031^{* *}$ \\
Relational Perception & 0.038887 & 0.046052 & 0.84 & 0.398 \\
Self-Efficacy & & & & \\
Educational Perception & 0.29801 & 0.085827 & 3.47 & $0.001^{\star * *}$ \\
Structural Perception & 0.301415 & 0.154084 & 1.96 & $0.050^{* *}$ \\
Relational Perception & 0.022129 & 0.08803 & 0.25 & 0.802 \\
\hline
\end{tabular}

Furthermore, the correlation between perception of educational support and entrepreneurial orientation has a coefficient value of 0.29801 with a significance level of 0.001 . This shows that the perception of educational support has a positive and significant effect on the self-efficacy. The perception of structural support also has a positive and 
significant effect on the self-efficacy with a coefficient value of 0.301415 and significance level of 0.050 . However, the perception of relational support does not significantly affect the self-efficacy where the coefficient value is 0.022129 and the significance level is 0.802 .

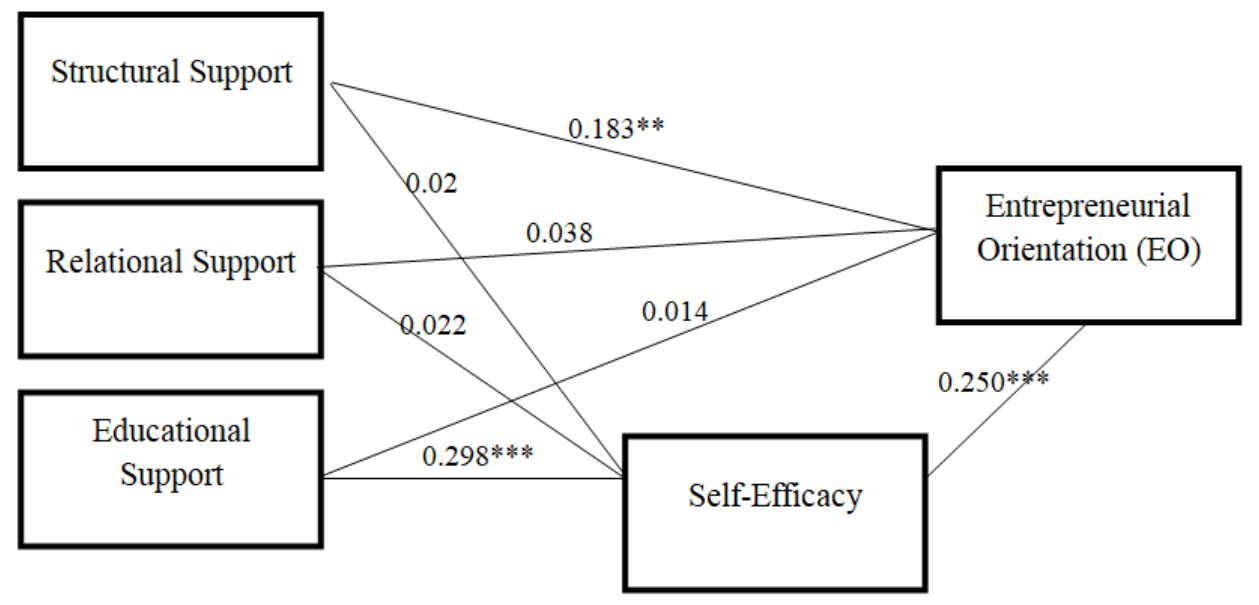

Figure 2 - Structural Equation Model

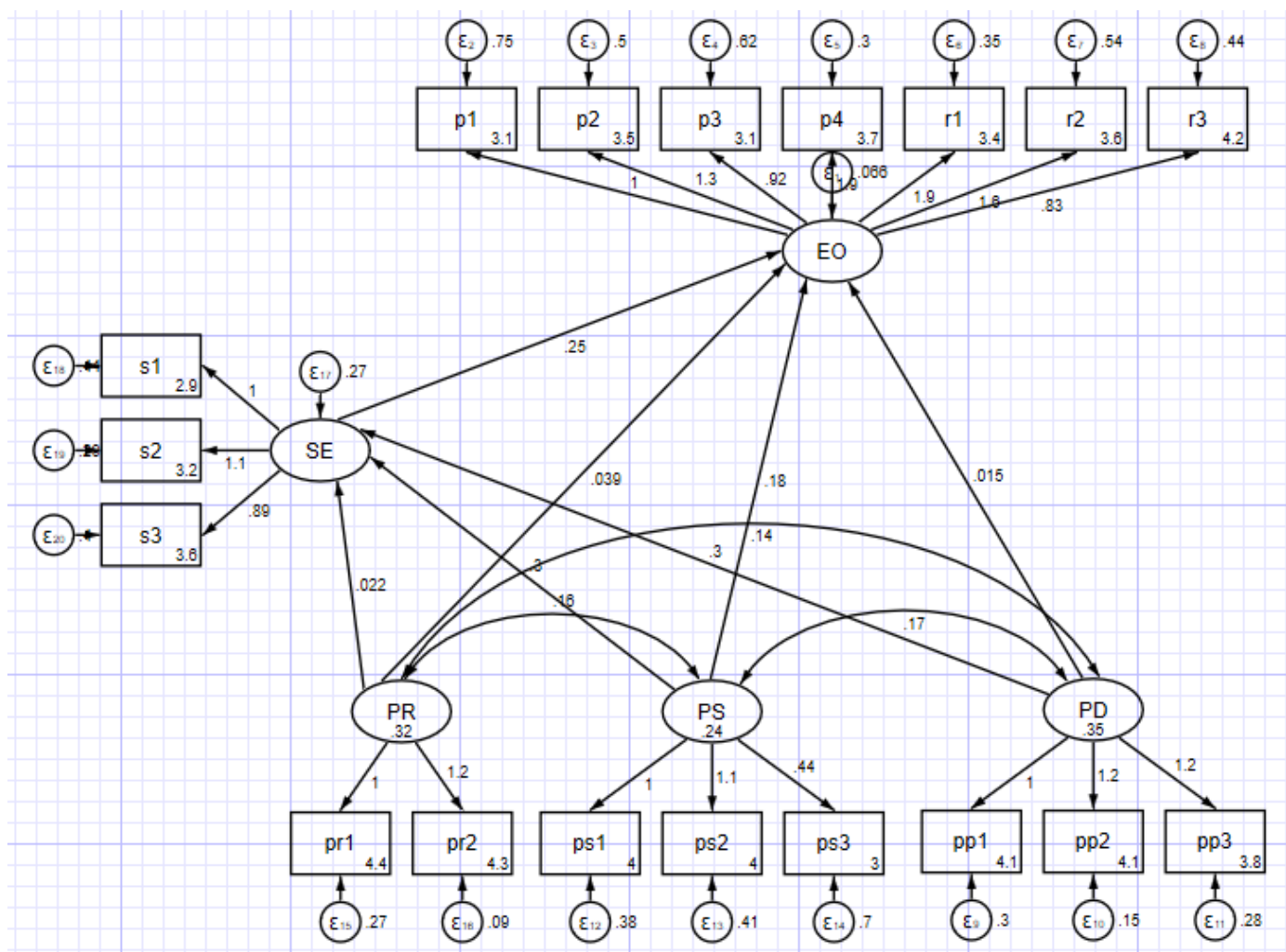

Figure 3 - Structural Equation Model using Stata

Self-efficacy has a positive and significant effect on the entrepreneurial orientation. This finding is in line with research done by Mueller \& Dato (2013). McGee et al. (2009) explained that self-efficacy was one of the factors of successful entrepreneurship. Moreover, Bandura (1986) said that self-efficacy was believe in abilities. Forbes (2005) argued that when someone believed in his/her ability to do business, his/her tendency to do entrepreneurship would be higher. In contrast, when someone had low confidence in his/her ability to do entrepreneurship, his/her tendency towards entrepreneurship would be lower. Previous research (Luthje and Franke 2003; Pittaway et al. 2010) found that self-efficacy 
could determine individual tendency to start a new business since it depicted the belief in their business.

The perception of educational support directly does not significantly affect the entrepreneurial orientation. However, when mediated by self-efficacy, the perception of educational support has a positive and significant effect on the entrepreneurial orientation. It shows that building entrepreneurial orientation in education must be accompanied by selfefficacy. Accordingly, the students would not only obtain knowledge but also awaken their confidence to carry out entrepreneurship (Bandura, 1997).

The perception of structural support directly has an effect on the entrepreneurial orientation and also has a significant effect when mediated by self-efficacy. This finding is in line with the research conducted by Dada and Watson (2013). They argued that structural support was a success factor in business success. Mutlutürk and Mardikyan (2018) argued that the regulations made by the agency or the government would determine the facilities for individuals to obtain capital, raw materials, and markets. As a consequence, when it is accessible, the tendency of someone to do business would increase.

\section{CONCLUSION}

This research provides an overview of the factors affecting university students' individual entrepreneurship orientation (IEO). The results reveal that the perception of structural support has a direct or indirect effect on the students' individual entrepreneurial orientation. Moreover, the perception of educational support does not directly affect the students' IEO. However, the perception of educational support will affect IEO when mediated by self-efficacy. This finding proves how entrepreneurship education implemented by universities does not have a direct effect on the students' tendencies towards entrepreneurship. It shows that individuals propensity to entrepreneurship required selfconfidence in abilities. It is important for the family, friends, and people around to give support to boost their confidence.

\section{REFERENCES}

1. Arshad, A. S., Rasli, A., Arshad, A. A., \& Zain, Z. M. (2014). The Impact of Entrepreneurial Orientation on Business Performance: A Study of Technology-based SMEs in Malaysia. Procedia - Social and Behavioral Sciences, 130, 46-53. doi:10.1016/j.sbspro.2014.04.006

2. Audretsch, D.B. (2007). The entrepreneurial society. New York: Oxford University Press.

3. Avlonitis, G. J., \& Salavou, H. E. (2007). Entrepreneurial orientation of SMEs, product innovativeness, and performance. Journal of Business Research, 60(5), 566-575. doi:10.1016/j.jbusres.2007.01.001

4. Bandura, A., \& Jourden, F. J. (1991). Self-regulatory mechanisms governing the impact of social comparison on complex decision making. Journal of Personality and Social Psychology, 60(6), 941-951.

5. Basso, O., Fayolle, A., \& Bouchard, V. (2009). Entrepreneurial Orientation: The Making of a Concept. The International Journal of Entrepreneurship and Innovation, 10(4), 313321. doi: $10.5367 / 000000009790012327$

6. Covin, J.G. and Slevin, D.P. (1991) A Conceptual Model of Entrepreneurship as a Firm Behavior. Entrepreneurship Theory and Practice, 16, 7-25.

7. Dada, O., \& Watson, A. (2013). Entrepreneurial orientation and the franchise system: Organisational antecedents and performance outcomes. European Journal of Marketing, 47(5/6), 790-812.

8. Dada, O., \& Watson, A. (2013). The effect of entrepreneurial orientation on the franchise relationship. International Small Business Journal, 31(8), 955-977.

9. Drnovšek, M., Wincent, J., \& Cardon, M. S. (2010). Entrepreneurial self-efficacy and business start-up: developing a multi-dimensional definition. International Journal of Entrepreneurial Behavior \& Research, 16(4), 329-348. doi:10.1108/13552551011054516 
10. Forbes, D. P. (2005). "Are Some Entrepreneurs More Overconfident than Others?," Journal of Business Venturing 20(5), 623-640

11. Gelaidan, H. M., \& Abdullateef, A. O. (2017). Entrepreneurial intentions of business students in Malaysia. Journal of Small Business and Enterprise Development, 24(1), 5467. doi:10.1108/jsbed-06-2016-0078

12. Giacomin, O., Janssen, F., Pruett, M., Shinnar, R. S., Llopis, F., \& Toney, B. (2010). Entrepreneurial intentions, motivations and barriers: Differences among American, Asian and European students. International Entrepreneurship and Management Journal, 7(2), 219-238. doi:10.1007/s11365-010-0155-y

13. Gorman, G., Hanlon, D., \& King, W. (1997). Some Research Perspectives on Entrepreneurship Education, Enterprise Education and Education for Small Business Management: A Ten-Year Literature Review. International Small Business Journal: Researching Entrepreneurship, 15(3), 56-77. doi:10.1177/0266242697153004

14. Holienka, M., Mrva, M. \& Marcin, P. (2013). Role of family entrepreneurial role models in determining students' preferences towards entrepreneurship. ICERI2013 Proceedings, 3722-3730.

15. Ismail, M., Khalid, S. A., Othman, M., Jusoff, H. K., Rahman, N. A., Kassim, K. M., \& Zain, R. S. (2009). Entrepreneurial Intention among Malaysian Undergraduates. International Journal of Business and Management, 4(10). doi:10.5539/ijbm.v4n10p54

16. Kollmann, T., Christofor, J., \& Kuckertz, A. (2007). Explaining individual entrepreneurial orientation: conceptualisation of a cross-cultural research framework. International Journal of Entrepreneurship and Small Business, 4(3), 325. doi:10.1504/ijesb.2007.013255

17. Kropp, F., Lindsay, N. J., \& Shoham, A. (2008). Entrepreneurial orientation and international entrepreneurial business venture startup. International Journal of Entrepreneurial Behavior \& Research, 14(2), 102-117. doi:10.1108/13552550810863080

18. Krueger, N. F., Reilly, M. D., \& Carsrud, A. L. (2000). Competing models of entrepreneurial intentions. Journal of Business Venturing, 15(5-6), 411-432. doi:10.1016/s0883-9026(98)00033-0

19. Lee, S. M., \& Peterson, S. J. (2000). Culture, entrepreneurial orientation, and global competitiveness. Journal of World Business, 35(4), 401-416. doi:10.1016/s10909516(00)00045-6

20. Lumpkin, G. T., \& Dess, G. G. (1996). Clarifying the Entrepreneurial Orientation Construct and Linking It to Performance. The Academy of Management Review, 21(1), 135. doi: $10.2307 / 258632$

21. Luthje, C., and N. Franke (2003). "The Making of an Entrepreneur: Testing a Model of Entrepreneurial Intent among Engineering Students at MIT," R\&D Management 33(2), 135-146.

22. Mason, M. C., Floreani, J., Miani, S., Beltrame, F., \& Cappelletto, R. (2015). Understanding the Impact of Entrepreneurial Orientation on Smes' Performance. the Role of the Financing Structure. Procedia Economics and Finance, 23, 1649-1661. doi:10.1016/s2212-5671(15)00470-0

23. Matlay, H. (2009). Entrepreneurship education in the UK. Journal of Small Business and Enterprise Development, 16(2), 355-368. doi:10.1108/14626000910956100

24. McGee, J. E., \& Peterson, M. (2017). The Long-Term Impact of Entrepreneurial SelfEfficacy and Entrepreneurial Orientation on Venture Performance. Journal of Small Business Management. doi:10.1111/jsbm.12324

25. McGee, J. E., Peterson, M., Mueller, S. L., \& Sequeira, J. M. (2009). Entrepreneurial selfefficacy: Refining the measure. Entrepreneurship Theory and Practice, 33(4), 965-988

26. Mthanti, T., \& Ojah, K. (2017). Entrepreneurial orientation (EO): Measurement and policy implications of entrepreneurship at the macroeconomic level. Research Policy, 46(4), 724-739. doi:10.1016/j.respol.2017.01.012

27. Mueller, S. L., \& Dato-on, M. C. (2013). A cross cultural study of gender-role orientation and entrepreneurial self-efficacy. International Entrepreneurship and Management Journal, 9(1), 1-20. 
28. Parvaneh Gelard. (2011). Impact of some contextual factors on entrepreneurial intention of university students. African Journal of Business Management, 5(26). doi:10.5897/ajbm10.891

29. Pittaway, L., E. Rodriguez-Falcon, O. Aiyegbayo, and A. King (2010). "The Role of Entrepreneurship Clubs and Societies in Entrepreneurial Learning," International Small Business Journal 29(1), 37-57.

30. Robinson, S., Stubberud, H.A. (1991). Elements of entrepreneurial orientation and their relationship to entrepreneurial intent. Journal of Entrepreneurship Education, 17(2), 1-11.

31. Rua, O. M. M. M. L. (2019). Contributions of Entrepreneurial Orientation to Competitive Advantage. Entrepreneurial Orientation and Opportunities for Global Economic Growth, 136-153. doi:10.4018/978-1-5225-6942-8.ch007

32. Turker, D., \& Sonmez Selcuk, S. (2009). Which factors affect entrepreneurial intention of university students? Journal of European Industrial Training, 33(2), 142-159. doi:10.1108/03090590910939049

33. World Economic Forum (2009). Educating the next wave of entrepreneurs: Unlocking entrepreneurial capabilities to meet the global challenges of the 21st century. Geneva, Switzerland: World Economic Forum

34. Yusoff, A., Ahmad, N. H., \& Abdul Halim, H. (2019). Unravelling agropreneurship activities among Malaysian Gen Y. International Journal of Entrepreneurial Behavior \& Research, 25(3), 457-479. doi:10.1108/ijebr-07-2017-0213 